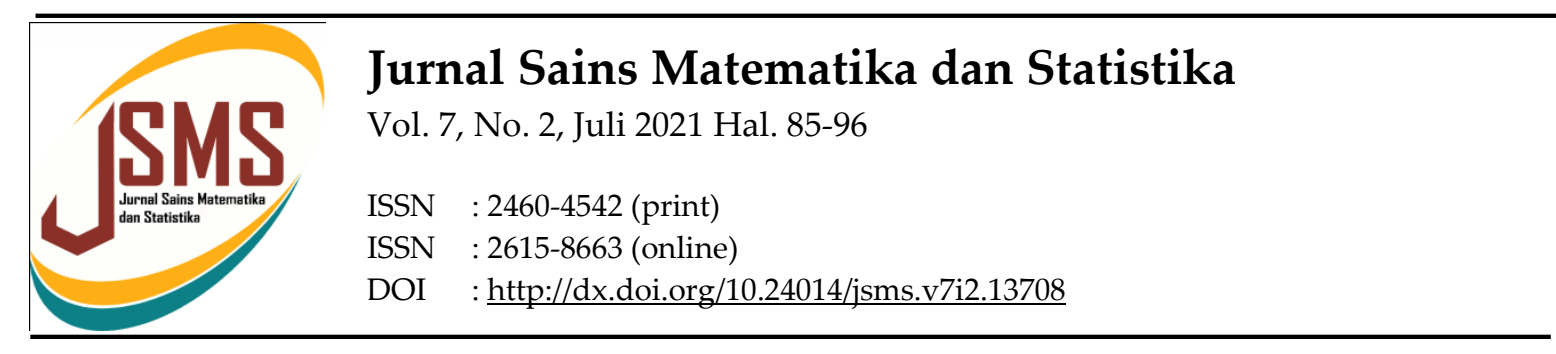

\title{
Model Penyebaran Perilaku Merokok Berdasarkan Faktor Biologis dan Lingkungan di Provinsi Riau
}

\author{
Irma Suryani' ${ }^{1}$, Mohammad Soleh ${ }^{2}$, Habibul Kelana ${ }^{3}$ \\ 1,2 Prodi Matematika, UIN Sultan Syarif Kasim Riau \\ Jl. HR. Soebrantas No. 155 Simpang Baru, Panam, Pekanbaru, 28293 \\ 3 Prodi Matematika, UIN Sultan Syarif Kasim Riau \\ Jl. HR Soebrantas No. 155 Simpang Baru, Panam, Pekanbaru, 28293 \\ Email: irma.suryani@uin-suska.ac.id ${ }^{1}$, msoleh@uin-suska.ac.id²
}

\begin{abstract}
Abstrak
Paper ini membahas tentang penyebaran perilaku merokok berdasarkan faktor biologis dan faktor lingkungan di Provinsi Riau. Model perilaku merokok $\left(S, S_{T}, D, A, R\right)$ adalah model yang digunakan pada paper ini untuk melihat seberapa besar faktor biologis dan faktor lingkungan terhadap penyebaran perilaku merokok di Provinsi Riau. Titik ekuilibrium ditentukan dengan menyelesaikan persamaan pada model yang digunakan dan diuji kestabilannya dengan kriteria nilai eigen dan Routh Hurwitz. Dari model diperoleh dua titik ekuilibrium yaitu titik ekuilibrium bebas rokok dan titik ekuilibrium endemik rokok. Hasil yang diperoleh dari penelitian ini adalah titik ekulibrium bebas rokok dan titik ekuilibrium endemik stabil asimtotik lokal.
\end{abstract}

Kata Kunci: Kriteria Routh-Hurwitz, Model $\boldsymbol{S}, \boldsymbol{S}_{T}, \boldsymbol{D}, \boldsymbol{A}, \boldsymbol{R}$, Stabtil Asimtotik, Titik Ekuilibrium

\begin{abstract}
This paper discusses about spread of smoking behavior based on biological factors and environmental factors in Riau Province. The Smoking Behavior Models $\left(\mathrm{S}, \mathrm{S}_{\mathrm{T}}, \mathrm{D}, \mathrm{A}, \mathrm{R}\right)$ are model used in this paper to see how much biological and environmental factors affect the spread of smoking behavior in Riau Province. The equilibrium is determined by solving the equations in the models and the stability is tested by the eigenvalue and Routh Hurwitz criteria. From model could have two equilibrium points namely the non-smoking equilibrium point and the endemic equilibrium point of the cigarette. The results obtained are a non-smoking equilibrium point and an endemic equilibrium point that is asymptotically stable locally.
\end{abstract}

Keywords: Asymtotic Stability, Equilibrium, Routh-Hurwitz Criteria, $\boldsymbol{S}, \boldsymbol{S}_{T}, \boldsymbol{D}, \boldsymbol{A}, \boldsymbol{R}$ Model. 


\section{Pendahuluan}

Perilaku merokok saat ini sangat menjadi perhatian bagi kesehatan orang-orang yang ada disekitarnya. Rokok merupakan salah satu ancaman kesehatan bagi masyarakat karena rokok dapat membahayakan orang yang merokok (perokok aktif) maupun orang yang tidak merokok yang ada di sekitar perokok (perokok pasif). Dari penelitian 10 tahun terakhir menunjukkan lebih dari 50\% perokok meninggal dunia karena kecanduan. Diperkirakan tahun 2030 nanti terdapat 8 juta orang di dunia akan meninggal dunia setiap tahunnya karena rokok[16]. Rokok mengandung kurang lebih 4000 senyawa kimia, setidaknya 200 senyawa kimia beracun dan berbahaya bagi tubuh, dan 43 lagi mengakibatkan kanker. Di Indonesia, anak-anak sudah mulai merokok pada usia 9 tahun. Data WHO juga semakin mempertegas bahwa seluruh jumlah perokok yang ada di dunia sebanyak $30 \%$ adalah kaum remaja[17].

Ada banyak alasan yang melatarbelakangi perilaku merokok, antaralain adalah faktor biologis dan lingkungan. Secara biologis, nikotin yang terkandung dalam rokok menekan kemampuan otak untuk mengalami kenikmatan, karenanya perokok membutuhkan kadar nikotin yang lebih lagi untuk mencapai tingkat kepuasan dan ketergantungan seseorang. Sementara faktor lingkungan salah satu yakni individu yang melakukan hubungan pertemanan dengan seseorang yang perokok sehingga mengakibatkan seseorang yang tadinya tidak merokok lalu merokok. Merokok bagi sebagian orang sudah merupakan kebiasaan yang sulit untuk dihilangkan, karena hampir dilakukan setiap hari dan setiap saat. Rokok telah benar-benar menjadi barang adiktif di seluruh dunia dan semua orang tahu bahayanya. Bukan hanya bagi perokok aktif saja tetapi perokok pasif juga terkena paparan bahayanya asap rokok dari perokok aktif dan jauh lebih berbahaya[14].

Di Provinsi Riau dari data Survei Sosial Ekonomi Nasional (Susenas) 2017, diperoleh bahwa 25,56\% pemuda Riau adalah perokok. Artinya, 1 dari 4 pemuda di Riau merokok, baik rokok tembakau maupun elektrik. Sementara itu, jumlah pemuda perokok di pedesaan lebih banyak daripada di perkotaan. Sampai dengan 2017, pemuda perokok di Riau telah memasuki fase membahayakan[20].

Hal ini sangat mengkhawatirkan sehingga perlu dilakukan penelitian terhadap penyebaran perilaku merokok di Riau. Penyebaran tentang model perilaku merokok telah banyak dilakukan guna membentuk model dari penyebaran perilaku merokok, salah satunya Fainaini Nurul [5] yang melakukan penelitian tentang penyebaran perilaku merokok dengan menggunakan tipe SEIR. Dalam penelitiannya, pertumbuhan jumlah perokok lebih besar dari kematian dan laju populasi berhenti merokok. Selanjutnya penelitian lain juga dilakukan oleh Hanisar [8] yang telah meneliti tentang pemodelan matematika tipe SEIR pada populasi merokok. Hanif menjelaskan titik bebas perokok bersifat stabil asimtotik dan epidemik bersifat stabil. Braham [3] juga meneliti penyebaran populasi merokok menggunakan Tipe SEIRS. Hasilnya menunjukkan keadaan stabil jika syarat-syarat parameter yang diberikan terpenuhi.

Selanjutnya, Resmawan dan Nurwan [15] telah melakukan penelitian analisis kestabilan sistem pada model matematika penyebaran populasi perokok yang hasilnya diperoleh bahwa kestabilan ekuilibrium diperoleh jika syarat $R_{0}$ nya terpenuhi. Dan Govan [6] juga telah melakukan penelitian membangun model penyebaran perilaku merokok berdasarkan faktor biologis dan faktor lingkungan. Dalam penelitiannya 
diperoleh bahwa perilaku merokok tidak akan hilang dari populasi. Penelitian terkait pemodelan perilaku merokok dapat dilihat dalam penelitin [5],[7],[3],[15] dan [6].

Dalam penelitian ini, penulis tertarik untuk membahas penelitian Govan [6] dengan penambahan asumsi perokok mencoba-coba mempengaruhi subpopulasi rentan dan mengambil kasus di Provinsi Riau. Berdasarkan dari latar belakang tersebut, penulis tertarik meneliti tentang penyebaran perilaku merokok berdasarkan faktor Biologis dan Lingkungan di Provinsi Riau.

\section{Metode Penelitian}

Langkah analisis penelitian ini disusun berdasarkan analisis penyebaran perilaku merokok berdasarkan faktor biologis dan lingkungan di Provinsi Riau adalah:

1. Membuat asumsi-asumsi yang akan dilakukan.

2. Membentuk model tipe $\mathrm{S}, S_{T}, \mathrm{D}, \mathrm{A}, \mathrm{R}$

3. Mendefinisikan parameter yang digunakan pada model matematika, variabel yang digunakan adalah:

$S_{T}$ : Subpopulasi yang diberikan treatment.

$S$ : Subpopulasi yang berpotensi merokok.

$D$ : Subpopulasi yang mencoba merokok.

$A$ : Subpopulasi perokok.

$R$ : Subpopulasi yang telah berhenti merokok.

$\alpha_{1}$ : tingkat kelahiran yang rentan terpengaruh.

$\alpha_{2}$ : tingkat kelahiran yang telah diberi treatment.

$\mu$ : tingkat kematian murni.

$\tau$ : jumlah kontak populasi perokok dengan mencoba merokok.

$\gamma$ : tingkat berhenti merokok.

$\rho$ : tingkat pertumbuhan merokok.

$\sigma$ : kembalinya perokok yang sembuh menjadi perokok.

$v$ : tingkat kematian yang diakibatkan dari merokok.

$B$ : kemugkinan menjadi perokok setelah kontak dengan perokok potensial.

$\beta$ : laju pertumbuhan subpopulasi rentan menjadi perokok coba-coba.

4. Mencari titik kritis dari model yang didapatkan, selanjutnya di evaluasi menggunakan matriks Jacobian.

5. Analisis kestabilan sistem dengan cara melihat tanda akar-akar polinomial karakteristik dari matriks Jacobian yang telah dievaluasi pada titik kritis. Karena polinomial karakteristik dari matriks Jacobian yang diperoleh berderajat tinggi, maka digunakan bantuan kriteria Routh-Hurwitz untuk mempermudah.

Melakukan simulasi dengan memasukkan nilai-nilai parameter yang telah ditentukan ke dalam parameter.

\subsection{Landasan Teori}

\subsubsection{Titik Ekuilibrium Dan Analisis Kestabilan}

Suatu sistem persamaan differensial dikatakan setimbang jika sistem tidak mengalami perubahan sepanjang waktu (konstan). Pada model ini, terdapat dua titik ekuilibrium, yaitu titik ekuilibrium bebas penyakit dan titik ekuilibrium endemik 
penyakit. Titik ekuilibrium bebas penyakit terjadi jika dalam suatu populasi tidak terdapat individu yang terinfeksi penyakit dan titik ekuilibrium endemik penyakit yaitu suatu keadaan populasi tersebut selalu terdapat individu yang terinfeksi penyakit.

Analisis kestabilan dilakukan untuk mengetahui informasi yang menggambarkan perilaku sistem pada titik ekuilibrium. Keadaan setimbang tersebut dikatakan stabil jika semua solusi yang dekat dengan titik ekuilibrium menuju titik ekuilibrium tersebut. Berikut ini diberikan definisi tentang ekuilibrium dan kestabilan:

Definisi 1 [13] Titik $\bar{x} \in R^{n}$ disebut titik ekuilibrium jika $f(\bar{x})=0$

Definisi 2 [11] Titik ekuilibrium $x$ yang memenuhi $f(x)=0$ dikatakan

1. Stabil jika untuk setiap $\varepsilon>0$ terdapat $\delta(\varepsilon)>0$, sedemikian sehingga untuk setiap solusi $x(t)$ yang memenuhi $\left\|x\left(t, x_{0}\right)-\bar{x}\right\|<\delta$ yang berakibat $\left\|x\left(t, x_{0}\right)-\bar{x}\right\|<\varepsilon$ untuk setiap $t \geq 0$

2. Stabil asimtotik jika $\bar{x}$ stabil dan terdapat $\delta_{1}>0$, sehingga $\left\|x\left(t, x_{0}\right)-\bar{x}\right\|<\delta_{1}$ yang berakibat $\lim _{t \rightarrow \infty}\left\|x\left(t, x_{0}\right)-\bar{x}\right\|=0$

3. Tidak stabil jika titik ekuilibrium tidak memenuhi (1).

Kestabilan titik ekuilibrium $x$ dapat ditentukan dengan memperhatikan nilai-nilai eigen, yaitu $\lambda_{i}=1,2, \cdots, n$ yang diperoleh dari persamaan karakteristik.

Definisi 3 [18] Misal diberikan Sistem Persamaan Diferensial (SPD) linier sebagai berikut:

$$
\dot{x}=A x
$$

dengan

$$
A=\left[\begin{array}{ll}
a & b \\
c & d
\end{array}\right]
$$

Maka persamaan karakteristik SPD pada persamaan (1), yaitu $(A-\lambda I) x=0$ dapat ditulis menjadi:

$$
a \lambda^{2}-b \lambda+c=0
$$

Maka dari persamaan (2) diperoleh nilai nilai eigen sebagai berikut:

$$
\lambda_{1,2}=\frac{-b \pm \sqrt{b^{2}-4 a c}}{2 a}
$$

Kestabilan dari titik ekuilibrium dapat ditentukan berdasarkan nilai eigen dari matriks Jacobian. Kriteria kestabilan titik ekuilibrium dapat disajikan pada teorema berikut:

Teorema 1 [19] Diberikan persamaan diferensial $\dot{\boldsymbol{x}}=A \boldsymbol{x}$ dengan A adalah matriks berukuran $n \times n$ memiliki $k$ nilai eigen yang berbeda $\lambda_{1}, \lambda_{2}, \cdots, \lambda_{n}$ dengan $k<n$ maka:

a. Titik ekuilibrium $\dot{x}$ dikatakan stabil asimtotik, jika dan hanya jika $\left.R_{e} \dot{(} \lambda_{i}\right)<0$ untuk setiap $i=1,2, \cdots, k$.

b. $\quad$ Titik ekuilibrium $\dot{x}$ dikatakan stabil, jika dan hanya jika $R_{e}\left(\lambda_{i}\right) \leq 0$ untuk setiap $i=1,2, \cdots, k$.

c. Titik ekuilibrium $\dot{x}$ dikatakan tidak stabil, jika dan hanya jika $R_{e}\left(\lambda_{i}\right)>0$ untuk setiap $i=1,2, \cdots, k$. 


\subsubsection{Kriteria Routh - Hurwitz[7]}

Berdasarkan Teorema 1 untuk menguji sifat kestabilan diperlukan perhitungan untuk menentukan nilai-nilai eigen dari matriks jacobian di titik ekulibrium. Kriteria RouthHurwitz merupakan salah satu alternatif untuk menentukan nilai eigen tersebut.

Diberikan suatu sistem persamaan karakteristik dalam bentuk polinomial sebagai berikut:

$$
f(s)=a_{0}+a_{1} S(n-1)+a_{0} S^{n}+\ldots+a_{n}{ }_{1} S+a_{n}
$$

jika persamaan (2.15) mempunyai bagian real negatif maka

$\frac{a_{1}}{a_{0}}>0, \frac{a_{2}}{a_{0}}>0, \ldots \frac{a_{n}}{a_{0}}>0$

Definisi 4 [9] Diberikan polinomial (4) dengan $a_{0}$ positif dan $a_{k}$ bilangan real, $k=1,2,3, \ldots n$. Matriks Hurwitz untuk persamaaan (4) didefinisikan sebagai matriks bujur sangkar berukuran $n \times n$ yang berbentuk sebagai berikut:

$$
H=\left[\begin{array}{ccccccc}
a_{1} & a_{0} & 0 & 0 & \cdots & 0 & 0 \\
a_{3} & a_{2} & a_{1} & a_{0} & \cdots & 0 & 0 \\
a_{5} & a_{4} & a_{3} & a_{2} & \cdots & 0 & 0 \\
\vdots & \vdots & \vdots & \vdots & \cdots & \vdots & \vdots \\
0 & 0 & 0 & 0 & \cdots & a_{n-1} & a_{n-2} \\
0 & 0 & 0 & 0 & \cdots & 0 & a_{n}
\end{array}\right]
$$

Determinan Hurwitz tingkat ke- $k$, dinotasikan dengan $\Delta k ; k=1,2, \ldots n$ yang dibentuk dari matriks Hurwitz (6), didefinisikan sebagai berikut:

$$
\begin{aligned}
& \Delta_{1}=\left\lfloor a_{1}\right\rfloor \\
& \Delta 2=\left[\begin{array}{ll}
a_{1} & a_{0} \\
a_{3} & a_{2}
\end{array}\right] \\
& \Delta_{3}=\left[\begin{array}{ccc}
a_{1} & a_{0} & 0 \\
a_{3} & a_{2} & a_{1} \\
a_{5} & a_{4} & a_{3}
\end{array}\right] \\
& H=\left[\begin{array}{ccccccc}
a_{1} & a_{0} & 0 & 0 & \cdots & 0 & 0 \\
a_{3} & a_{2} & a_{1} & a_{0} & \cdots & 0 & 0 \\
a_{5} & a_{4} & a_{3} & a_{2} & \cdots & 0 & 0 \\
\vdots & \vdots & \vdots & \vdots & \cdots & \vdots & \vdots \\
0 & 0 & 0 & 0 & \cdots & a_{n-1} & a_{n-2} \\
0 & 0 & 0 & 0 & \cdots & 0 & a_{n}
\end{array}\right]
\end{aligned}
$$

\section{Hasil dan Pembahasan}

\subsection{Model Dinamik Penyebaran Perilaku Merokok}

Adapun asumsi-asumsi yang digunakan pada model matematika ini adalah sebagai berikut: 
1. Setiap individu yang lahir dalam populasi diasumsikan rentan menjadi perokok diakibatkan penularan perilaku merokok terjadi karena adanya interaksi antara subpopulasi yang rentan dengan subpopulasi perokok dan subpopulasi perokok mencoba-coba.

2. Perlakuan (treatment) misalnya berupa penyuluhan hanya diberikan kepada subpopulasi perokok yang rentan.

3. Populasi tertutup, hanya di Provinsi Riau.

4. Faktor biologis dan faktor lingkungan.

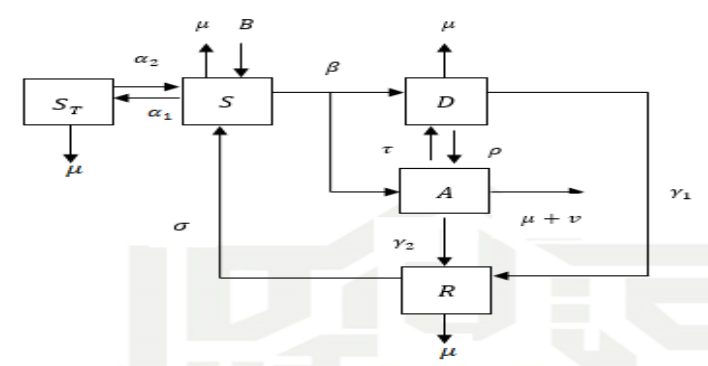

Gambar 1. Model Penyebaran Perilaku Merokok

Berdasarkan diagram alir dari Gambar 1 maka dapat dibentuk sistem persamaan differensial sebagai berikut :

$$
\begin{aligned}
& \frac{d S}{d t}=B-\left(\beta D+\beta A+\mu+\alpha_{1}\right) S+\sigma R+\alpha_{2} S_{T} \\
& \frac{d S_{T}}{d t}=\alpha_{1} S-\left(\alpha_{2}+\mu\right) S_{T} \\
& \frac{d D}{d t}=\beta S D+\tau A-\left(\rho+\gamma_{1}+\mu\right) D \\
& \frac{d A}{d t}=\beta S A+\rho D-\left(\tau+\gamma_{2}+\mu+v\right) A \\
& \frac{d R}{d t}=\gamma_{1} D+\gamma_{2} A-(\mu+\sigma) R \\
& \alpha_{1}>0, \alpha_{2}>0, \gamma_{1}>0, \gamma_{2}>0, \mu>0, \rho>0, \sigma>0, \tau>0, v>0 \\
& \text { dengan } S(t)+S_{T}(t)+D(t)+A(t)+R(t)=1
\end{aligned}
$$

\subsection{Titik Ekuilibrium Penyebaran Perilaku Merokok}

\section{a. Titik Ekuilibrium Bebas Rokok}

Pada titik ekuilbrium bebas rokok berarti di dalam populasi tidak ada individu yang dapat menyebarkan pengaruh rokok terhadap populasi. Jadi titik ekuilibrium bebas rokok pada model penyebaran perilaku merokok dinotasikan dengan $A=0$ dengan $\frac{d s_{t}}{d t}=0, \frac{d S}{d t}=0, \frac{d D}{d t}=0, \frac{d A}{d t}=0, \frac{d R}{d t}=0$. Sehingga diperoleh titik kesetimbangan bebas rokok, sebagai berikut:

$$
T_{1}=\left(\frac{\alpha_{1} B}{\left(\alpha_{2} \mu+\alpha_{1} \mu+\mu^{2}\right)}, \frac{\left(\alpha_{2}+\mu\right) B}{\left(\alpha_{2} \mu+\alpha_{1} \mu+\mu^{2}\right)}, 0,0,0\right)
$$

\section{b. Titik Ekuilibrium Endemik Rokok}


Titik ekuilibrium endemik terjadi apabila $D^{*} \neq 0$ dan $A^{*} \neq 0$. Pada model epidemik penyebaran perilaku merokok diperoleh dari $\frac{d A}{d t}=0$ dengan $A=A^{*}$. Sehingga didapat nilai titik ekuilibrium endemik rokok sebagai berikut:

$$
\begin{aligned}
& S^{*}= \frac{\tau \rho+y}{\beta(\beta S-x)}, \\
& S_{T}{ }^{*}= \frac{\alpha_{1}(\tau \rho+\gamma)}{\left(\alpha_{2}+\mu\right)(\beta(\beta S-x)} \\
& D^{*}= \frac{\mathrm{z} R^{*}\left(\beta S^{*}-\mathrm{x}\right)}{\left(\gamma_{1}\left(\beta S^{*}-\mathrm{x}\right)-\gamma_{2} \rho\right)} \\
& A^{*}= \frac{-\rho D^{*}}{\left(\beta S^{*}-x\right)} \\
& \frac{B-\left(\beta\left(\frac{z R^{*}\left(\beta S^{*}-x\right)-\rho D^{*} \gamma_{1}+\left(\beta S^{*}-x\right)}{\left(\gamma_{1}\left(\beta S^{*}-x\right)\right)\left(\beta S^{*}-x\right)}\right)-\mu-\alpha_{1}\right) \frac{-\tau \rho+y}{\beta\left(\beta S^{*}-x\right)}}{\alpha_{1} \frac{-\tau \rho+\gamma}{\beta\left(\beta S^{*}-x\right)}} \\
& R^{*}= \frac{\alpha_{2}}{\left(\alpha_{2}-\mu\right)} \\
& \sigma
\end{aligned}
$$

\subsection{Kestabilan Titik Ekuilibrium Bebas Rokok}

Kestabilan titik ekuilibrium bebas rokok dapat dilihat dengan menggunakan matriks Jacobian berdasarkan Persamaan (7)-(11) diperoleh matriks Jacobian $J_{1}$, sebagai berikut:

$$
J_{1}=\left[\begin{array}{ccccc}
-\beta D-\beta A-\mu-\alpha_{1} & \alpha_{2} & -\beta S & -\beta S & \sigma \\
\alpha_{1} & -\alpha_{2}-\mu & 0 & 0 & 0 \\
\beta D & 0 & \beta S-\left(\rho+\gamma_{1}+\mu\right) & \tau & 0 \\
\beta A & 0 & \rho & \beta S-\left(\tau+\gamma_{2}+\mu+v\right) & 0 \\
0 & 0 & \gamma_{1} & \gamma_{2} & -\mu-\sigma
\end{array}\right]
$$

Selanjutnya yaitu mencari titik kestabilan bebas rokok disubtitusikan ke dalam matriks Jacobian $J_{1}$ dengan menggunakan rumus $\operatorname{det}\left(\lambda I-J_{2}\right)=0$, sehingga diperoleh: $\lambda_{1}+\mu=0, \lambda_{1}=-\mu, \lambda_{1}<0$

$\lambda_{2}+\mu+\alpha_{1}+\alpha_{2}=0, \lambda_{2}=-\mu-\alpha_{1}-\alpha_{2}, \lambda_{2}<0$

$\lambda_{3}+\mu+\sigma, \lambda_{3}=-\mu-\sigma, \lambda_{3}<0$

$\lambda_{4}-\beta S+\mu+\frac{1}{2}\left(\rho+\tau+v+\gamma_{1}+\gamma_{2}\right)$

$+\frac{1}{2} \sqrt{\rho^{2}+2 \rho \tau-2 \rho v+2 \rho \gamma_{1}-2 \rho \gamma_{2}+\tau^{2}+2 \tau v+2 \tau \gamma_{1}+2 \tau \gamma_{2}+v^{2}-2 v \gamma_{1}+2 v \gamma_{2}}$

$-\gamma_{1}^{2}-2 \gamma_{1} \gamma_{2}+\gamma_{2}^{2}$

$\lambda_{4}=\beta \mathrm{S}-\mu-\frac{1}{2}\left(\rho-\tau-\mathrm{v}-\gamma_{1}-\gamma_{2}\right)$

$-\frac{1}{2} \sqrt{\rho^{2}-2 \rho \tau+2 \rho v-2 \rho \gamma_{1}+2 \rho \gamma_{2}-\tau^{2}-2 \tau v-2 \tau \gamma_{1}-2 \tau \gamma_{2}-v^{2}+2 v \gamma_{1}-2 v \gamma_{2}}+\gamma_{1}^{2}$

$\lambda_{4}<0$

$+2 \gamma_{1} \gamma_{2}-\gamma_{2}^{2}$

$\lambda_{5}-\beta S+\mu+\frac{1}{2}\left(\rho+\tau+v+\gamma_{1}+\gamma_{2}\right)$

$-\frac{1}{2} \sqrt{\rho^{2}+2 \rho \tau-2 \rho v+2 \rho \gamma_{1}-2 \rho \gamma_{2}+\tau^{2}+2 \tau v+2 \tau \gamma_{1}+2 \tau \gamma_{2}+v^{2}-2 v \gamma_{1}+2 v \gamma_{2}}$

$-\gamma_{1}^{2}-2 \gamma_{1} \gamma_{2}+\gamma_{2}^{2}$ 


$$
\begin{aligned}
& \lambda_{5}=\beta S-\mu-\frac{1}{2}\left(\rho-\tau-v-\gamma_{1}-\gamma_{2}\right) \\
& +\frac{1}{2} \sqrt{\rho^{2}-2 \rho \tau+2 \rho v-2 \rho \gamma_{1}+2 \rho \gamma_{2}-\tau^{2}-2 \tau v-2 \tau \gamma_{1}-2 \tau \gamma_{2}-v^{2}+2 v \gamma_{1}-2 v \gamma_{2}}+\gamma_{1}{ }^{2} \\
& \lambda_{5}<0 \\
& +2 \gamma_{1} \gamma_{2}-\gamma_{2}^{2}
\end{aligned}
$$

Karena nilai eigin $\lambda_{1}<0, \lambda_{2}<0, \lambda_{3}<0, \lambda_{4}<0$ dan $\lambda_{5}<0$, berdasarkan Teorema 1 maka didapat bahwa titik ekuilibrium bebas rokok stabil asimtotik. Artinya, perilaku merokok sudah tidak ada dalam populasi.

\subsection{Kestabilan Titik Ekuilibrium Endemik Rokok}

Kestabilan titik ekuilibrium endemik rokok dapat dilihat dengan menggunakan matriks jacobian, sebagai berikut:

$\operatorname{det}\left[\begin{array}{ccccc}\lambda+\beta D+\beta A+\mu+\alpha_{1} & -\alpha_{2} & \beta S & \beta S & -\sigma \\ -\alpha_{1} & \lambda+\alpha_{2}+\mu & 0 & 0 & 0 \\ -\beta D & 0 & \lambda-\left(\beta S-\left(\rho+\gamma_{1}+\mu\right)\right) & -\tau & 0 \\ -\beta A & 0 & -\rho & \lambda-\left(\beta S-\left(\tau+\gamma_{2}+\mu+v\right)\right) & 0 \\ 0 & 0 & -\gamma_{1} & -\gamma_{2} & \lambda+\mu+\sigma\end{array}\right]$

dari hasil jacobian maka didapat hasil karakteristiknya sebagai berikut:

$a_{0} \lambda^{5}+a_{1} \lambda^{4}+a_{2} \lambda^{3}+a_{3} \lambda^{2}+a_{4} \lambda+a_{5}=0$

Berdasarkan Teorema 1 persamaan karakteristik didapat koefisien bernilai positif apabila Determinan dari Routh-Hurwitz positif, maka didapatkan hasilnya:

$$
\begin{aligned}
& H_{1}=\left[a_{1}\right], a_{1}>0 \\
& H_{2}=\left[\begin{array}{cc}
a_{1} & 1 \\
a_{3} & a_{2}
\end{array}\right], a_{1} a_{2}-a_{2}>0 \\
& H_{3}=\left[\begin{array}{ccc}
a_{1} & 1 & 0 \\
a_{3} & a_{2} & a_{1} \\
a_{5} & a_{4} & a_{3}
\end{array}\right],\left(a_{1} a_{2} a_{3}+a_{1} a_{2} a_{4}\right)-\left(a_{3}^{2}+a_{1}^{2} a_{4}\right)>0 \\
& H_{4}=\left[\begin{array}{cccc}
a_{1} & 1 & 0 & 0 \\
a_{3} & a_{2} & a_{1} & 1 \\
a_{5} & a_{4} & a_{3} & a_{2} \\
0 & a_{6} & a_{5} & a_{4}
\end{array}\right], a_{1}^{3} a_{2} a_{6}-a_{1}^{2} a_{4}^{2}-a_{2}^{2} a_{1} a_{5}+a_{1} a_{2} a_{3} a_{4}-a_{1} a_{6} a_{3}+2 a_{1} a_{4} a_{5}+a_{5} a_{2} a_{3} \\
& -a_{3}^{2} a_{4}-a_{5}^{2}>0 \\
& H_{5}=\left[\begin{array}{ccccc}
a_{1} & 1 & 0 & 0 & 0 \\
a_{3} & a_{2} & a_{1} & 1 & 0 \\
a_{5} & a_{4} & a_{3} & a_{2} & a_{1} \\
0 & a_{6} & a_{5} & a_{4} & a_{3} \\
0 & 0 & 0 & a_{6} & a_{5}
\end{array}\right], 2 a_{1}^{2} a_{2} a_{5} a_{6}-a_{1}^{3} a_{6}^{2}+a_{1}^{2} a_{3} a_{4} a_{6}+a_{1} a_{3} a_{3} a_{4} a_{5}+2 a_{1} a_{4} a_{5}^{2}+ \\
& a_{2} a_{3} a_{5}^{2}+a_{3} a_{6}^{3}-a_{1}^{2} a_{4}^{2} a_{5}-a_{1} a_{2}^{2} a_{5}^{2}-a_{1} a_{2} a_{3}^{2} a_{6}-3 a_{1} a_{3} a_{5} a_{6}-a_{5} a_{3}^{2} a_{4}-a_{5}^{3}>0 \text {. }
\end{aligned}
$$

Berdasarkan Teorema 1, maka titik ekuilibrium endemik adalah stabil asimtotik lokal, yang artinya perilaku merokok tidak akan hilang dari populasi dan perokok juga dapat menularkan perilaku merokok kepada subpopulasi yang rentan.

\subsection{Simulasi}

\subsubsection{Titik Ekuilibrium Bebas Rokok}


Nilai parameter yang diambil berdasarkan jurnal Juni Puspita [10] seperti terlihat pada Tabel 1 dan data yang digunakan di bawah ini hasil Survei Sosial Ekonomi Nasional 2017, sebagai berikut:

Tabel 1. Nilai Parameter pada Titik Ekuilibrium Bebas Rokok

\begin{tabular}{|c|c|c|}
\hline Parameter & Nilai & Sumber \\
\hline B & 10 & \\
\hline $\boldsymbol{\alpha}_{\mathbf{1}}$ & 1 & Juni (2016) \\
\hline $\boldsymbol{\alpha}_{\mathbf{2}}$ & 1 & Juni (2016) \\
\hline $\boldsymbol{\beta}$ & 0,0000009 & \\
\hline $\boldsymbol{\gamma}_{\mathbf{1}}$ & 0,09 & Erturk, dkk (2012 \\
\hline $\boldsymbol{\gamma}_{\mathbf{2}}$ & 0,01 & Vika, dkk (2013) \\
\hline $\boldsymbol{\rho}$ & 0,03 & Zeb, dkk (2013) \\
\hline $\boldsymbol{\sigma}$ & 0,5 & Juni (2016) \\
\hline $\boldsymbol{\tau}$ & 0,01 & Vika, dkk (2013) \\
\hline $\boldsymbol{\mu}$ & 0,0000002 & \\
\hline $\boldsymbol{v}$ & 0,01 & Erturk, dkk (2012 \\
\hline
\end{tabular}

Sumber: Juni (2016)

nilai $S(0)=1665, S_{T}(0)=1665, D(0)=1236, A(0)=1452, R(0)=39,9$ sehingga dinamika populasi bebas penyakit dapat dilihat pada gambar berikut:

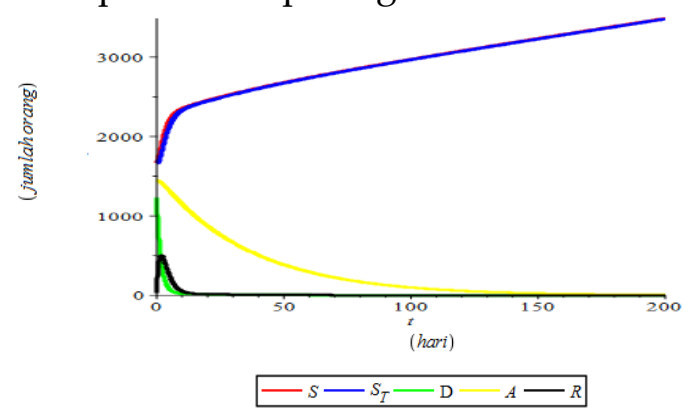

Gambar 2. Kestabilan Titik Ekuilibrium Bebas Rokok

Berdasarkan Gambar 2 di atas terlihat bahwa $S$ terjadi peningkatan karena ada individu yang rentan masuk ke populasi, untuk $S_{T}$ mengalami peningkatan karena subpopulasi yang rentan masuk ke subpopulasi yang diberi treatment, untuk $D$ mengalami penurunan karena ada kontak langsung dengan subpopulasi perokok dan dengan subpopulasi rentan yang diberi treatment dan juga adanya yang berhenti dari merokok, untuk $A$ mengalami penurunan karena subpopulasi perokok berada dalam kondisi bebas rokok, sementara untuk $R$ mengalami penurunan karena laju berhenti subpopulasi perokok dan juga karena kematian alami. 


\subsubsection{Titik Ekuilibrium Endemik}

Untuk nilai parameter akan diasumsikan pada Tabel 2 dan data yang digunakan di bawah ini hasil dari Survei Sosial Ekonomi Nasional 2017, sebagai berikut:

Tabel 2. Nilai Parameter pada Titik Ekuilibrium Endemik

\begin{tabular}{|c|c|}
\hline Parameter & Nilai \\
\hline B & 10 \\
\hline $\boldsymbol{\alpha}_{\mathbf{1}}$ & 0,0000001 \\
\hline $\boldsymbol{\alpha}_{\mathbf{2}}$ & 0,0000001 \\
\hline $\boldsymbol{\beta}$ & 0,0000009 \\
\hline $\boldsymbol{\gamma}_{\boldsymbol{1}}$ & 0,0000009 \\
\hline $\boldsymbol{\gamma}_{\boldsymbol{2}}$ & 0,0000001 \\
\hline $\boldsymbol{\rho}$ & 0,0000003 \\
\hline $\boldsymbol{\sigma}$ & 0,0000005 \\
\hline $\boldsymbol{\tau}$ & 0,0000001 \\
\hline $\boldsymbol{\mu}$ & 0,0000002 \\
\hline $\boldsymbol{v}$ & 0,0000001 \\
\hline
\end{tabular}

sehingga dinamika populasi bebas penyakit dapat dilihat pada gambar berikut:

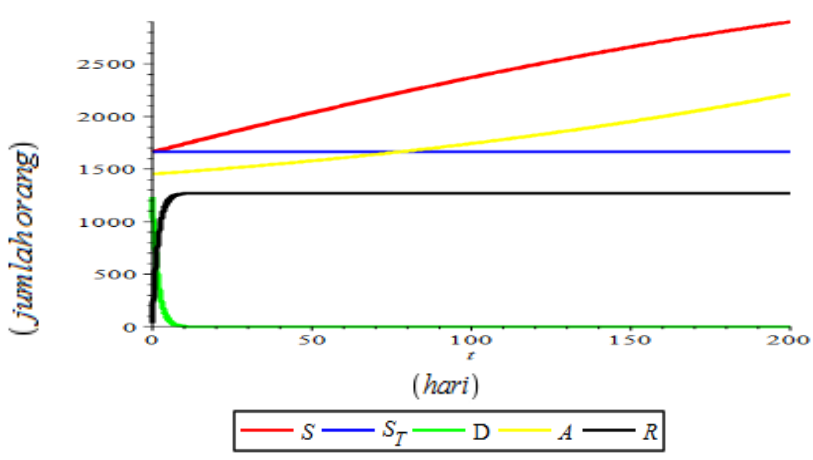

Gambar 3. Kestabilan Titik Ekuilibrium Endemik

Berdasarkan Gambar 3, S mengalami penaikan karena adanya individu lahir kemungkinan akan menjadi perokok setelah melakukan kontak dengan subpopulasi perokok. Sementara $S_{T}$ mengalami sedikit penurunan karena tingkat kelahiran yang telah diberi treatmeant kemungkinan akan menjadi rentan terpengaruhi oleh subpopulasi perokok. Antara $D$ dan $A$ ada dua perbedaan, untuk $D$ mengalami penurunan kemungkinan perokok yang mencoba-coba akan berganti menjadi subpopulasi perokok atau menjadi perokok aktif dan bisa juga karena kematian alami, sementara untuk $A$ mengalami kenaikan karena subpopulasi perokok mencoba menjadi subpopulasi perokok dan sampai kapanpun peredaran merokok tidak akan pernah abis dalam populasi, begitu pun di Propinsi Riau tidak akan hilang peredaran merokok dari populasi. 


\section{Kesimpulan}

Dari penelitian yang telah dilakukan maka dapat disimpulkan:

1. Ada dua titik ekuilibrium pada model yaitu:

b. Titik ekulibrium bebas rokok, yaitu:

$$
T_{1}=\left(\frac{\alpha_{1} B}{\left(\alpha_{2} \mu+\alpha_{1} \mu+\mu^{2}\right)}, \frac{\left(\alpha_{2}+\mu\right) B}{\left(\alpha_{2} \mu+\alpha_{1} \mu+\mu^{2}\right)}, 0,0,0\right)
$$

c. Titik ekulirium endemik, yaitu:

dengan,

$$
T_{2}=\left\{S^{*}, S_{T}^{*}, D^{*}, A^{*}, R^{*},\right\}
$$

$$
\begin{aligned}
S^{*}= & \frac{\tau \rho+y}{\beta(\beta S-x)}, \\
S_{T}{ }^{*} & =\frac{\alpha_{1}(\tau \rho+\gamma)}{\left(\alpha_{2}+\mu\right)(\beta(\beta S-x)} \\
D^{*}= & \frac{\mathrm{z} R^{*}\left(\beta S^{*}-\mathrm{x}\right)}{\left(\gamma_{1}\left(\beta S^{*}-\mathrm{x}\right)-\gamma_{2} \rho\right)} \\
A^{*}= & \frac{-\rho D^{*}}{\left(\beta S^{*}-x\right)} \\
& \frac{B-\left(\beta\left(\frac{z R^{*}\left(\beta S^{*}-x\right)-\rho D^{*} \gamma_{1}+\left(\beta S^{*}-x\right)}{\left(\gamma_{1}\left(\beta S^{*}-x\right)\right)\left(\beta S^{*}-x\right)}\right)-\mu-\alpha_{1}\right) \frac{-\tau \rho+y}{\beta\left(\beta S^{*}-x\right)}}{\alpha_{1} \frac{-\tau \rho+\gamma}{\beta\left(\beta S^{*}-x\right)}} \\
R^{*}= & \frac{\alpha_{2} \frac{\left(\alpha_{2}-\mu\right)}{\sigma}}{\sigma a p a t k a n}
\end{aligned}
$$

2. Kestabilan ekuilibrium pada model yang didapatkan adalah titik ekulibrium bebas rokok stabil asimtotik lokal jika nilai eigen bernilai negatif. Artinya, individu perokok tidak ada di dalam populasi dan populasi rentan meningkat karena adanya treatment yang diberikan sehingga perilaku merokok hilang dari populasi. Sedangkan titik ekuilibrium endemik akan stabil asimtotik lokal jika nilai eigen bernilai positif. Artinya, perilaku merokok tidak akan hilang dari populasi dan perokok juga dapat menularkan perilaku merokok kepada subpopulasi yang rentan.

\section{Daftar Pustaka}

[1] Anton, Rorres. Aljabar Linier Elementer, Versi Aplikasi, Jakarta, Erlangga, 2004.

[2] Allen, Model Of Organizational Commitment, 2007.

[3] Barham, Siti Maryam, Pemodelan Matematika Pada Penyebaran populasi Perokok Menggunakan Tipe SEIR, https://www.researchgate.net/publication/341379182, Matematika Biologi, 2020.

[4] Driessche \& Watmough., Reproduction Number and Sub-Threshold Endemic Equilibria for Comparmentall Model od Deseae Transmission, Mathemtical Biosciences 180, Hal 29, 2002.

[5] Faisnaini, N.A., Pemodelan Matematika Dan Studi Kesetimbangan pada Penyebaran Pengaruh Perilaku Merokok Menggunakan Tipe SEIR, Skripsi, Fakultas MIPA Universitas Lampung, 2018. 
[6] Govan, R. Ratianingsih, dan J.W. Puspita, Membangun Model Penyebaran Perilaku Merokok Berdasarkan Faktor Biologis Dan Faktor Lingkungan Sosial, Jurnal Ilmiah Matematika dan Terapan, 2016.

[7] Grantmacher, F.H., Applications Of The Theory Matrices, Intersciences Publisher, New York, 1959.

[8] Hanisar, Pemodelan Matematika Tipe SEIR pada Populasi Perokok, Skripsi, Fakultas MIPA Universitas Halu Oleo Kendri, 2016.

[9] Hale, J, K dan H, Kocak, Dynamic Bifurcation, Springer-Verlag New York, 1991.

[10] Juni, P., Membangun Penyebaran Perilaku Merokok Berdasarkan Faktor Biologis dan Lingkungan Sosial, Skripsi, Fakultas MIPA Universitas Tadulako, 2016.

[11] Olders, G, J., Mathematical Systems Theory Intermediatethird Edition, The Netherlands: VSSD, 2003.

[12] Kelley, W.G and Peterson, A.C., The Theory of Differential Equations, Springer-Verlag, New York, 2010.

[13] Perko, L., Differensial Equation and Dynamical System, Springer- verlag, New York, 1991.

[14] Renny, A, N, P., Hubungan antara Dimensi Kepribadian Big Five dengan Prilaku Merokok pada Remaja, Skripsi Fakultas Psikologi, Universitas Islam Negeri Syarif Hidayatullah, Jakarta, 2011.

[15] Resmawan dan Nurwan, Analisis Kestabilan Sistem Pada Model Matematika Penyebaran Populasi Perokok, Jurnal Matematika Integratif, 2020.

[16] Saititi,A., Strategi Rahasia Berhenti Merokok, Data Media, Jakarta, 2009.

[17] Smet, B., Psikologi Kesehatan, PT Gramedia Widiasarana Indonesia, Jakarta, 1994.

[18] Strogatz, Nonlinear Dynamics And Chaos. Cambridge: Harvard University, 1994.

[19] Subiono, Matematika Sistem. Surabaya: Jurusan Matematika, FMIPA-ITS. 2010.

[20] https://pekanbaru.tribunnews.com/2018/11/15/di-balik-kepulan-asap-rokokpemuda-riau 